\title{
GROWING UP AMID THE RELIGION AND SCIENCE AFFAIR: A PERSPECTIVE FROM INDOLOGY
}

\author{
by Thomas B. Ellis
}

\begin{abstract}
This article identifies the tropes of "maturity" and "immaturity" in the dialogue between religion and science. On both sides of the aisle, authors charge, either directly or indirectly, that their dissenting interlocutors are not mature enough to see the value of their respective positions. Such accusations have recently emerged in discussions pertaining to Hindu theology, Indology, and science. Those who dismiss the substance dualism of Hindu yoga, according to Jonathan B. Edelmann, evince immaturity. Appeals to Hindu yoga are yet one more appeal to religious experience. Indeed, what we find in Edelmann's text is an appeal to appreciate the private, unverifiable - or falsifiable, for that matter- "insights" of Hindu yogis. Yogic experience is interminably steeped in motivated perception and confirmation bias. There is simply no good evidence or rational argument to take yogic claims seriously. Insofar as that is the case, Indology must achieve consilience with the natural and human sciences, remaining thereby reductive of such supernatural claims.
\end{abstract}

Accusations of immaturity occasionally animate the discussion pertaining to the compatibility, or not, of religion and science. Perhaps the most memorable of such accusations belongs to Sigmund Freud. Freud (1927) characterized religion as infantile insofar as it encourages adults to redeploy 
strategies children use to handle hardship and heartache. As children turn to their parents for solace, so too religious adults project a parent-like figure into the cosmos in hopes that the figure will similarly provide solace. Failing to recognize that religion is the result of a wish fulfillment perpetuates immaturity. Freud suggested that we needed to grow up and that a scientific education to reality was the ticket to such maturation. Science supposedly tempers our infantile proclivities.

While it is the infantile strategy of turning to divine parents that explicitly informs Freud's perspective on religion, I believe we ought to take note of the complementary argument in his text. Freud suggests that we ought to beware of allowing what we would like to be the case to inform what we believe is actually the case. If our worldview just so happens to corroborate what we would like to believe, then we ought to pause for a moment of critical reflection. It is, of course, possible that what we want to be true is in fact true, but as the recent debates concerning science and religion testify, this is clearly not the case for everyone. I argue that intellectual maturity demands that we accept what is the case and by so doing dispose of wishful thinking in the toy chest of childhood.

The latest accusation of immaturity I have come across is in Jonathan B. Edelmann's Hindu Theology and Biology: The Bhägavata Purāna and Contemporary Theory. Edelmann suggests that there exists at present a certain popular interest in painting with broad strokes the incompatibilities between science and religion, and, what is more, either an implicit or explicit prescription to do away with religion altogether. This is a position of immaturity for Edelmann. Popular (mis)understandings of religion and science apparently result from nothing more than "'mythologized" distinctions" (2012, 22). According to Edelmann, it would appear that the time is nigh for a "mature mind" to see beyond such putatively facile and, one should infer, immature characterizations. Religion's detractors simply fail to engage with maturity religion's perspective. Edelmann writes, "A true and genuine dialogue does not occur between texts, but between people who have, to use an Indian theme, 'seen' the texts; that is, they have assimilated and understood the texts through sustained and critical reflection with a mature mind" (2012, 22-23, emphasis added). Edelmann stands not alone in such a charge. Many theologians today are indeed often wont to characterize their scientific detractors as being too simpleminded with regard to the supposed subtleties of theology (Haught 2008). I disagree. Failing to understand and/or assimilate the subtleties of theological texts may not be the actual reason why scientific detractors dismiss religion.

Despite Edelmann's initial characterization, there is nothing uniquely Indian about using the trope of vision to express comprehension. We in "the West" routinely use such language. Surely it is not uncommon for someone to say, "I see what you mean," once the point in question is understood. 
Comprehension is not what makes "seen" a particularly "Indian theme." I am, in this regard, a bit suspicious that Edelmann's initial characterization is tendentious. Let us be clear about this particular Indian theme.

The "Indian theme" of "seen" is not simply a matter of "assimilation" and "understanding," insofar as these words do not necessarily mean that one has acquired some "experiential knowledge." For instance, I believe I can thoroughly comprehend the dualistic philosophy of SāṃkyaYoga without having to practice yoga or have some yogic experience. To claim otherwise-standard practice for phenomenologists and theologians alike-is to invite all of the rationally and empirically warranted criticism that has been leveled at the phenomenology of religion over the past few decades (Fitzgerald 2000; Wiebe 2000; McCutcheon 2001; Segal 1983). But that is precisely what is "unique" about the Indian use of "seen." The "Indian theme" pertains to some sort of knowledge gained via the practice and ultimately experience of devotional yoga. In this regard, "yogicperception," as I so call it, would seem to be an Indian euphemism for "experience," a term itself hotly contested in the academic study of religion (Taves 2009). Vaishnava theology, at least as Edelmann presents it, appears to be a systematic elaboration of, if not in fact apology for metaphysical and epistemological claims based on what is rightfully taken to be "religious experience"; after all, "theology is largely devoted to making sense of and bringing some logical order to the claims of popular religion" (McCauley 2011, 228). Immaturity, according to Edelmann's account, would thus seem to connote stubborn skepticism regarding such claims.

Recognizing that Edelmann does not directly attribute "immaturity" to any one thinker, or popularizer as the case may be, we can all the same gather from a footnote on page 12 that he has at least associated such immaturity with the likes of Daniel Dennett (2006), Richard Dawkins (2006), and Sam Harris (2007). Of course, according to his implied definition of maturity, Edelmann would be right. Dennett, Dawkins, and Harris are disinclined to accept the claims of religious devotees, especially when they are so clearly out of keeping with the results of research in the natural and human sciences: "Today's sciences of the mind cast doubt on metaphysical intuitions" (Edis 2008, 124).

Hindu theology, not to mention the various traditions often referred to monolithically and thus problematically as "Hinduism" (Flood 1996), is incompatible with contemporary science. This point is well demonstrated in C. Mackenzie Brown's Hindu Perspectives on Evolution: Darwin, Dharma, and Design (2012). Brown documents not only the history of classical and contemporary Hindu metaphysics and epistemology but also the incompatibility of such Hindu traditions with regard to contemporary science. The fact of the matter is that contemporary scientific methods and results indirectly support a particular metaphysic as well as epistemology that are at odds with Hindu theology and religion, generally conceived. 
Brown and Edelmann, of course, disagree. Edelmann suggests that a dialogue is possible between, specifically, the biological sciences and the theology of the Bhägavata Purāna. I remain unconvinced. Brown's conclusions, on the other hand, indicate perhaps unsurprisingly that the Hindu traditions are no more compatible with science, broadly construed, than are Christianity and Islam. I agree with Brown.

In what follows, I will indicate where I believe the Hindu traditions and theologies run afoul of not only well-tested, scientific methods but also the resulting truth claims concerning what is real and what is not. Moreover, I will show that Hindu traditions routinely "discover" exactly what most human animals hope to be the case. In this regard, I believe Hindu traditions are routinely guilty of motivated perception and confirmation bias. While Freud would certainly chalk up such failures in reasoning to emotional needs-a theme itself dating as far back as Lucretius-recent work in the cognitive sciences demonstrates that there may be something more to religion's appeal than merely emotional satisfaction (McCauley 2011). Religion in all its guises may be the result of an emotionally satisfying, yet all the same cognitive, mistake. Perhaps it is the widespread proclivity to indulge this mistake that must be outgrown if we are to assess with any modicum of maturity the contributions of science and religionincluding Hindu traditions, of course - to an accurate understanding of ourselves, the world, and ultimately the universe. Likewise, and with respect to Indology, it would appear that many in the field, especially those interested in the religious and philosophical traditions of India, appear all-too-ready to allow unsupported claims emanating from the various yoga and dharma traditions to influence not only their own methods but also their metaphysics (Inden 1990). I propose that Indology must move beyond sympathetic translations and romantic apologetics and pursue an explanation of the dharma traditions that is consilient with the rest of the natural and human sciences (Ellis 2009, 2011; Wilson 1998).

The worldview currently enjoying scientific support and consensus is naturalism. "Naturalism" is for all intents and purposes interchangeable with "physicalism" and "materialism." The particle physicist Victor Stenger rightly notes, "According to our best current knowledge, the substance of the universe is matter and nothing else. So, until something other than matter is discovered, always at least a remote possibility, we can equate naturalism with materialism" $(2009,160)$. While its metaphysic is materialism, naturalism's epistemology is empirico-rationalism (Avalos 2005), meaning that what is considered true is that for which there is good empirical evidence and rational argument.

Concerning god(s), naturalism generally adopts a position of strong agnosticism (Ellis 2008). Strong agnostics, to be sure, function as atheists. They argue that no human animal can make any pronouncements whatsoever concerning supernatural entities, even though such entities 
may exist. In which case, all supernatural pronouncements are merely the products of human fancy. Appeals to private intuitions or revelations simply won't do. On the issue of a soul or mind being capable of existing outside of a physical medium, naturalism is rightfully atheistic. As we will see following, consciousness is the emergent property of a highly complex, physical system.

Naturalism is not the metaphysics and epistemology most people fancifully choose (Pyszczynski et al. 2003). Rather, it would seem to force itself upon the mature thinker as the result of abductive reasoning. Despite theistic accusations to the contrary, naturalism is "neither the a priori premise nor the logically necessary conclusion of methodological naturalism, but the well-grounded a posteriori result" (Forrest 2000, 19). Owen Flanagan similarly notes:

Supernatural concepts have no philosophical warrant. Furthermore, it is not just that such concepts are displaced only if we accept, from the start, a naturalistic or scientific vision of things. There simply are no good arguments-theological, philosophical, humanistic, or scientific - for beliefs in divine beings, miracles, or heavenly afterlives. (2002, xiii)

I agree. Religion simply fails to present any good evidence or argument for its various claims (Baggini 2003). Insofar as this is the case-and I believe it to be the case-religion's methods and claims, including of course those of the Hindu traditions, are incompatible with science's methods and claims. When the claims are truly incompatible, maturity counsels adopting the latter's. Many have and will disagree.

Over much of the twentieth century, the status of scientific methods and claims came under sustained scrutiny. Disciplines such as the history and sociology of science as well as the philosophy of science, for instance, often found it plausible to problematize scientific pursuits and results. To discuss what is actually true began to sound a bit naive, and by extension perhaps a bit immature. Science studies, generally conceived, seemed to support postmodern antirealism. For postmodernists, truth claims were increasingly considered the output of unrecognized and/or undetected ideologies. Science simply found what it presupposed. Thomas S. Kuhn (1962) (in)famously argued that all sciences operate within some paradigm and it is only in light of such paradigms that knowledge claims make any sense. The crucial implication of such a position was that the paradigms themselves were not and are not the result of scientific discovery. Paradigms would seem to be relative and/or subjective. For many, relativizing science in this way ostensibly counsels the democratic appeal to be open to alternative epistemologies and by extension metaphysics.

In her 2002 presidential address to the American Academy of Religion, Vasudha Narayanan adopts just such an antiscience position. She endorses openness to "epistemic diversity" and "corporeal knowledge." Highlighting its putatively ideological bent, Narayanan aligns contemporary science 
with cultural imperialism, appealing thereby to her audience's postcolonial sensibilities, if not in fact guilt. I concur with Donald Wiebe when he notes, "It appears, however, that the alternative sources of knowledge she proposes be taken seriously by the academy are essentially religious in character, involving the adoption of particular cosmological and metaphysical world views" (2006, 685). That is indeed the point. We must adopt a priori a different paradigm in order to recognize the contributions of various religious perspectives. Insofar as such a recommendation relies upon a postmodern relativistic stance, I must agree further with Wiebe when he notes that such relativism "has 'bought' the argument of the postmodernists to the effect that reason and scientific thought are themselves essentially ideological. That argument, however, is simply not persuasive" (Wiebe 2006, 688; see also Koertge 1998; Gross and Levitt 1994). Not only is it unpersuasive to scientific students of religion, but it is, curiously enough, equally unpersuasive to those marginalized worldviews that would ostensibly benefit from the adoption of such. To be sure, the overwhelming majority of Indian traditions are committed not to relativism but rather a robust correspondence theory of truth (Franco 1987). I do not believe it is such a stretch to claim that religious communities generally believe that what they believe is actually true (Segal 1983; Haught 2008).

Edelmann apparently senses the failure of the relativizing strategy. His approach attempts to show that Vaishnava theology is consistent with the best practices of mainstream science. Edelmann points out that both appeal to perception, inference, and authoritative testimony. Although science is often wont to deny its reliance on testimony- that is, authorityEdelmann is right to note such reliance. Science could not in fact exist without authoritative testimony. Scientists simply do not reinvent the wheel every time they enter the laboratory. Insofar as that is the case, scientists must rely on the discoveries of past scientists in order to move their respective fields forward. That being said, scientists are surely most cautious when it comes to relying on testimony. Not just any claim will do.

Authoritative testimony in science is predicated upon successful peer review. Peer review establishes the value of any scientific claim because it presumably forestalls the pernicious epistemological problems of motivated perception and confirmation bias. As the renowned physicist Richard P. Feynman correctly noted, we must be careful not to fool ourselves because fooling ourselves is the easiest thing to do. So much so is this the case that it has led Michael Shermer to posit that our default position is one of "belief-dependent realism" $(2011,5)$. We allow our preconceived beliefs to inform how we interpret the world, only grudgingly ceding such beliefs upon the presentation of robust evidence and argument to the contrary. Edelmann seemingly makes a similar argument for the Hindu traditions. He suggests that Hindu claims to truth are likewise based on authoritative testimony and peer review. I am unconvinced that this is the case. The 
similarity between scientific and Hindu testimony and peer review may be more impressionistic than substantive.

I argue that Hindu traditions, like all religious traditions, are replete with motivated perceptions and confirmation biases. I further argue that religious practitioners seldom, if ever, attempt to disconfirm their positions. With respect to devotional yoga, I am equally unconvinced that there is any way to peer review what are in effect experiences deemed yogic (Taves 2009). The so-called community of peers that vet Vaishnava claims - that is, the "sanga" (Edelmann 2012, 168) — rely on a most suspicious method for establishing authority:

One should first gain knowledge about canonical texts; then one should put that knowledge into practice by carrying out the various forms of devotional practices described in the Bhaggavata; and after time "knowledge about" the texts will become "knowledge of" the texts, if one properly performs the practice.... The text also says that by religious practice one can see Visnu in the heart; this latter claim is only open to verification or falsification by practitioners. (Edelmann 2012, 115)

This method seems imminently committed not to warranted skepticism but to unabashed motivated perception and confirmation bias. To be sure, one is to read the texts that make the claims. One is to engage in devotional practices - for example, meditation and yoga - that concentrate on the entities and realities proclaimed in the texts. Then, with diligence, one perceives what one was told one would perceive: "In Vaishnava thought there exists the idea that when a practitioner hears the testimony of the Bhaggavata and when they practice what they have heard, they will then have direct experience of the objects of which the Bhaggavata speaks" (Edelmann 2012, 170). To me, this walks and talks like motivated perception and confirmation bias, and it raises yet another difficulty.

As I hinted above, equally problematic is the fact that at no point in Edelmann's presentation of the similarities between Hindu theology and biology do we ever get the sense of what would falsify yogic perception. For evolutionary biology, falsification would be quite simple: a rabbit in the pre-Cambrian fossil record would do the trick. This is a curious omission on Edelmann's part insofar as such falsification is a standard of contemporary scientific practice. Indeed, how can one falsify a claim issuing from "phenomenological subjectivity"(Edelmann 2012, 89)? I argue that yogic perception is simply incapable of being falsified, or verified for that matter. Edelmann's appeal to Vaishnava peer review is unpersuasive. There is simply no guarantee that the yogic consensus is not manufactured post hoc. Truly, "variability in cultural representations is inescapable.... The accurate reproduction of mental representations is the rare exception in the transmission of ideas, even with the cultural scaffolding that texts can supply"(McCauley 2011, 241). We simply cannot be sure that what one yogi experiences is the same as that of another. In which case, it would seem 
terribly dubious to hang one's metaphysic on the claims of like-minded and like-motivated religious practitioners.

When scientists rest on the testimony of others, they have faith that the authoritative claims are about external, mind-independent realities. These realities are gotten to not by closing one's eyes and attempting to block out external, perceptual input-standard practice for many meditation strategies-but rather by engaging in experiments open to one and all to inspect, criticize, and ultimately replicate:

Science does not tolerate secret formulas, special sensitivities, or so-called singularities.... The steadfastness with which the scientific community demands the public availability of scientific claims and the replicability of scientific findings are the two most important pillars on which scientific methods' epistemic credibility rests. (McCauley 2011, 142)

It would seem to be the exact opposite for bhakti yoga. Yogic perception is exhaustively mind-dependent, internally generated, and wholly private. Through deep contemplation and meditation, the yogi claims to have contact with a reality that is beyond the reach of our everyday sense perceptions. By turning inward we supposedly come to know what is truly outward. I must admit that it seems more plausible and probable that yogis mistake internally generated brain states with extra-mental reality. For good or ill, I remain wholly unconvinced that the deafferentation of the right superior parietal lobe (Newberg et al. 2001) or micro-seizures in the temporal lobe (Persinger 1987) lend any insight whatsoever to what is actually true about us, the world, and/or universe. It is indeed "hard to see how by using less of our brains we can learn more about the universe, so this experience is most likely all in our heads" (Stenger 2009, 220). I believe Pascal Boyer is right to argue that there is something "deeply-I would say criminally-ambiguous" $(2010,63)$ about noting the neurological reality of such experiences, precisely because it would seem to intimate immediately that this neurological event corresponds with reality as such.

Although it may ultimately be only in degree, the difference between Edelmann's sense of yogic testimony and putative peer review and what actually takes place in scientific circles might as well be one in kind. Truly, in the absence of publicly reviewable evidence, yogic testimony is nothing more than anecdote. Accumulating anecdotes does not amount to accumulating data. Comparing anecdotes does not amount to peer review. Willfully consenting to anecdotes that confirm what you wish to be the case does not establish authority, and it is indeed the case that what the bhakti yogi experiences is exactly what his or her existentially troubled soul would wish to discover all along.

While it is true that dispassion is often counseled in the Hindu traditions, this should not be taken to mean, as Edelmann seemingly presents it, that the devotees are bereft of personal investment in their practices. He writes, 
"The idea in the Bhägavata (is) that detachment and dispassion are required to understand reality as it really is rather than as one would like it to be" (2012, 187) noting elsewhere, "Theology... is possible only when the reader is willing to set aside his or her personal hopes and wishes about the nature of reality (material and spiritual) and the meaning of the text, and is thereby ready to receive the text rather than impose a preconception on it" $(2012,185)$. I simply disagree. In fact, I propose that it is the exact opposite for the Hindu traditions, a point Edelmann's text itself seems to corroborate. He writes, "To be a good bhakti-yogin it is necessary to put aside one's hopes and wishes regarding the erroneous concept of the body as self, and the notion that the world is something that can be enjoyed independent of God" (2012, 161). We will examine in a moment just how "erroneous" this "concept" is from the scientific perspective. For now, I have to insist that the "erroneous concept" is not what the majority of Hindu Indians - not to mention most religious peoples (Flanagan 2002) hope is the case. The consistent marginalization, if not in fact outright disparagement of the Cārvaka system in India, clearly bears this out (Brown 2012).

Bhakti yogis often begin their search for truth with a very specific motivation: they are disgusted with the embodied, biological condition. This is amply borne out in the South Asian philosophical and religious literature (Masson 1976, 1980; Ellis 2011). Edelmann himself indicates as much: "The knowledge that leads one to renunciation and detachment from embodied life is often called vāiragya-jn̄āna” $(2012,196)$. Though amenable to various translations, väiragya can clearly be associated with disgust. Elsewhere he writes, "The characteristics of the self are described in [Bhägavata] 7.7.29 to help a grieving mother understand the difference between matter and self, which is supposed to help free her from suffering" $(2012,67)$. The practice of devotional yoga is anything but dispassionate and unmotivated, despite what the texts themselves may occasionally suggest. I argue that religious practitioners are not engaging in their practices to find out what reality is in itself, but rather precisely for how it relates to their particular predicaments and ultimately their socalled enlightenment. Edelmann cites the Sämkhya-kārikā 64: "From the study of the constituents of nature, the salvation-knowledge arises, 'I am not matter" (2012, 141, fn. 12). Bhakti yogis find exactly what they hope is the case- that is, that the self is not limited to the mortal body and, at least for the Vaishnava traditions, that Vishnu is in control of all.

Far from being dispassionate, bhakti yogis want something more than the algorithmic machinations of an insentient universe. They want to believe that consciousness is more than an emergent property of an exhaustively material system. This is precisely where the scientific and Hindu communities become irreconcilable. From cosmology (Krauss 
2012) to evolutionary development biology (Carroll 2006), the picture that is coming into focus is one that maintains that the universe and what little life there is therein are products of mindless, impersonal algorithms (Dennett 1995). It is this exhaustive physicalism that leads Flanagan (2007) to suggest that the really hard problem today is not an explanation of the physical origins of consciousness but rather the ability to find meaning in a seemingly metaphysically meaningless world. I dare say that Flanagan's perspective is not something he came to out of a desire for it to be true. In fact, he recognizes that "existential horror and unremitting nausea" (2002, 11 ) are probably the first responses to the contemporary scientific image. Emotional discomfort, however, ought not to inform our metaphysics. We, including Vaishnavas, ought not to fool ourselves.

While there are plenty of facts that one could, and ought to, consult when establishing a worldview by which one may then organize one's beliefs and behaviors, there are two topics that are of utmost concern when it comes to the discussion of science and religion generally, and on Edelmann's and Brown's recent accounts, the discussion of Hindu theology and science in particular-cosmogony and consciousness. These two topics are unsurprisingly central insofar as they appear to be the domains of final retreat for the God-(or Brahma)-of-the-gaps argument. Truly, the "irreducible complexity" and "complex specified information" arguments have met their matches (Young and Edis 2004). Accordingly, a good bit of theological energy is spent today arguing that consciousness is not reducible to its physical medium and that the universe as a whole calls out for an intelligent creator. These are admittedly hard problems, but I am unconvinced that they are intractable, or at least so intractable as to render all logical possibilities equally probable.

Was the universe intelligently created? Did the universe create itself? Was the so-called "Big Bang" a singular event or was it merely one episode among a potentially infinite number of such episodes occurring both serially and in parallel? These are the questions currently exercising the cosmologists. Have they been definitively settled once and for all? Of course not. That being said, I believe we can recognize that there are viable natural, mathematical models that indicate the universe in which we find ourselves is not as unique as a classical creationist may want to suggest. Inasmuch as the jury is not exhaustively in on this score, there remains the possibility of an intelligent creator, whether that creator is the god of the Abrahamic faiths or Vishnu of the Hindu, or some other entity that simply escapes our imagination. There is simply no way of knowing which, if any, such agencies are responsible for the universe, or multiverse, as the case plausibly is. The best we can do on this score is claim agnosticism. No religious authority can claim with any certainty anything certain about cosmogony or cosmology. What is certain, though, is that Hindu thinkers, both classical and contemporary, maintain insistently that an intelligent being must be involved from the 
beginning, either as a complement to or facilitator of the physical (Brown 2012). This is not the consensus of the cosmologists.

What theists generally tend to claim about the creation of the universe hangs on their position regarding the other of the two "hot button" issues animating the religion and science discussion-consciousness. In much the same way that the universe's origins remain uncertain-a point even RgVeda 10.129 seems to acknowledge, despite Dayananda Saraswati's indications to the contrary-many believe that the origins and nature of consciousness are themselves similarly inscrutable. Unfortunately, such seeming inscrutability supports a wide variety of rationally unwarranted speculation.

Perhaps the most popular speculation concerning consciousness pertains to substance dualism. Substance dualism holds that there are two fundamental elements or substances in reality. We find such dualisms in both Western and Eastern traditions. René Descartes, of course, is the most famous Western dualist. Descartes held that there are things that are extended in space and time (res extensa) and things that are not (res cogitans). The latter things enjoy the ability to know, reflect, and intend- that is, they enjoy sentience. Of course, Descartes ran into the trouble-as do all substance dualists - of how the two spheres interact. The Hindu dualists apparently skirt this problem by proclaiming that such interaction, though phenomenologically compelling, may be a mistake.

The most famous Hindu dualist would have to be Patañjali. Endorsing the Sāṃkya system of philosophy, Patañjali argued that there are indeed two general ontological categories - that is, purusa and prakrti. purusa is often understood to be a timeless and infinite source of consciousness. prakrti on the other hand is the material stuff of brute reality. Significantly for the present discussion, Sāmkya philosophy holds that mind (manas) and intelligence (buddhi) are actually part of the material nature that is prakrti. Edelman seems to suggest that this dissipates the mind-body problem for Hindus. It does and it doesn't.

There is no manas-deha (mind-body) problem for Patañjali insofar as both are considered elements of prakrti. However, there would seem to be the functionally equivalent cit-manas/deha problem. How indeed do purusa and prakrti interact? Patañjali gets out of this functionally equivalent conundrum by arguing that consciousness does not interact with the mind-body complex. In fact, suffering comes precisely from falsely believing there is such interaction (cf. Yoga Såtra 2, 17). Edelmann uses this position as a means of blunting the physicalism currently enjoying a growing consensus amid the mind sciences. He writes, "Reconciliation is possible because the Bhägavata posits three ontological categories: physical matter, the mind, and consciousness" $(2012,218)$. Accordingly, all of the research on the neural correlates of consciousness (NCC) simply addresses realities pertinent to prakrti and as such has no comment on fundamental 
consciousness-that is, purusa. The trouble with this position, however, is that not only is there no reason or evidence to believe that substance dualism is true, but there is absolutely no evidence or reason to posit the ontologically gratuitous three categories of the Vaishnava system. Edelmann disagrees.

It would appear at one point that Edelmann justifies the Vaishnava position by appealing to the work of Indologists. He writes, "Indologists have explored the notion of this non-sensual and non-physical perception, or the visions of those whose 'doors of the mind may be opened' $(R g$ 9.10.6; cf. $R g$ 4.11.2; quoted in Gonda 1963, 17)” (2012, 109). Believing rightly or wrongly that my training in Sanskrit and Indian philosophy allows me to speak as an Indologist, I will be the first to admit that my command of ancient Sanskrit texts that wax romantic about all sorts of special powers and insights does not constitute me as an authority on what consciousness actually is. It reminds me of a charge against one of William Lane Craig's favorite reasons for accepting the so-called evidence for the resurrection of Jesus of Nazareth: the majority of New Testament scholars attest to it. The majority of New Testament scholars attest to the evidence of the resurrection because they already believe in the resurrection. There is no evidence for such a miraculous event. Anecdotally speaking, many Indologists I know are equally romantic about the fantastic claims of yogis and fakirs. Skepticism regarding indigenous evidence and justifications does not seem to be part of Indological training. In this regard, consider some of the evidence Edelmann marshals for defending three ontological categories: "The way consciousness identifies with mind-brain relationships is analogous to the manner in which a dreamer identifies with a dream" $(2012,219)$; "Just as in a dream one falsely believes one has a connection with the dream" $(2012,121)$; "A dream has no intrinsic relationship with the life of the dreamer" $(2012,125)$. The third ontological category-that is, purusa - is ostensibly supported by an analogy with dreaming; however, the claim that a dream has nothing to do with the dreamer is unsupported. In fact, there are compelling reasons to think otherwise. For instance, threat simulation theory (TST) posits that one's dreams provide a safe "arena" in which to practice and thus hone evasion tactics that facilitate the survival of the dreamer when awake and actually experiencing threats to his or her well-being (Revonsuo 2000). According to TST, the dreamer and the dream are in effect one and the same. It is simply untrue that there is an obvious disconnect between dreamer and dream, and yet that is the argument many Hindu texts apparently make.

Edelmann also appeals to phenomenological awareness to support Vaishnavism's "ontologically queer substances" (Flanagan 2007, 86). He notes, "The movement from one state of consciousness to another, while retaining a sense of individuality and continuity, is taken as evidence that the self/consciousness is different from the mind-body complex" $(2012,69)$. Again, this is clearly not the only way to handle first-person 
phenomenal awareness. In fact, the Buddhist traditions take the same experiences and argue for the absence of such permanent consciousness and identity (Flanagan 2002, 2011). Likewise, the Cārvaka system proposes that consciousness is merely an epiphenomenal product of insentient matter, in which case "the Cârvaka perspective is especially significant in the modern context as it readily accommodates a Darwinian or Neo-Darwinian understanding of the universe with little or no need of theological or philosophical negotiation. As N. S. Dravid notes, the Cārvaka perspective is more or less the modern scientific view of the purely physico-chemical structure of the human body'" (Brown 2012, 24-25). In the absence of any truly uncontested evidence, it is simply not the case that dream analogies and phenomenological subjectivity unequivocally attest to what Edelmann and Vaishnava theology claim. What is more, I believe our current scientific theories regarding such matters are much more parsimonious.

Consciousness for most Hindus - both classical and contemporarycannot be reduced to the material (Brown 2012). That was clearly what Patańjali had, and yogis today have, in mind. On an emotional level, this is clearly understandable. Disembodied or disembodiable minds are existentially soothing. Of course, existential satisfaction cannot truly comment on ontological viability. Most philosophers of mind, not to mention neuropsychologists and neuroscientists, are thoroughgoing physicalists (Dennett 1991; Kim 2005; Searle 2005; Koch 2004; Flanagan 2002; Churchland 1988; Thagaard 2010). Outside of wishful thinking, there just does not appear at present any truly compelling reason to believe otherwise. Emotional appeals and certain unsubstantiated, firstperson declarations notwithstanding, consciousness does not seem capable of existing "outside" an appropriate physical medium. The notion that consciousness not only somehow exists free of a such medium but is also capable of realizing its intentions immediately is similarly something for which we have no evidence, experiential or otherwise, or rational reason to believe (Mackie 1982). Every experience we have with anything conscious involves physical mediation from start to finish. Indeed, "it becomes hard to think of a disembodied will that is an uncaused cause-after all, our own minds are nothing of the sort" (Edis 2008, 124). If the brain is properly functioning, we can expect consciousness to be present. If the brain is damaged, consciousness is similarly affected. If the brain is dead, consciousness is not. Despite religio-poetic attestations to the contrary, the mind is the brain and the brain is wholly material. Fortunately or unfortunately, proclaiming the physicality of mind does not put to rest all of the fantastic speculations regarding the nature of consciousness; after all, quantum mechanics is part of advanced physical theory today.

The complexities and confusions attending quantum mechanics would seem to invite all sorts of intellectual misdemeanors with respect to consciousness. Although we may presently suspend judgment on just how important quantum mechanics may be for consciousness, the pop 
quantum theorizing we find amid the Neo-Hindu and so-called "new age" communities is not only unwarranted but wholly unpersuasive (Brown 2012). I believe Stenger is correct when he writes:

The brain is not a quantum device. It operates for the most part according to Newtonian mechanics. The fact that the atoms in the brain operate on quantum principles does not change this conclusion. So do the atoms of a rock, and we are not considering rock consciousness. Most of the time the brain is "just" a computer carrying out deterministic mechanical algorithms in which a given input should always result in the same output. $(2009,195)$

Determinism does seem to be gaining ground (Harris 2012). Of course, certain Hindu traditions may want to contest Stenger's preclusion of rock consciousness. Advaita Vedānta, for instance, may support some sort of "weak theory of rock consciousness." If Brahman pervades all things or, and better yet, is ultimately all things, then consciousness animates the entire cosmos. As it is with Patañjali's queer ontology, so too with Advaita Vedānta's: outside of wishful thinking, the Vedāntic position appears scientifically and philosophically unwarranted.

If the contemporary scientific image is the most empirico-rationally warranted position to endorse, can we chalk up its opposite-namely the humanistic image (Flanagan 2002) — simply to emotional appeal? I don't believe so. Emotional appeal is starting to look like only one side of a more complicated coin. For good or ill, the other side may be even more troubling for religious communities.

Over the past couple of decades, great strides have been made in the cognitive sciences. Particular to our discussion, the cognitive science of religion (CSR) has begun to highlight our natural, cognitive proclivities to interpret information in rather peculiar ways. While classical psychology of religion was wont to highlight the emotional motivations for living the religious life, we are now coming to understand that such emotional satisfactions find their complement and ultimately support in the cognitive ease with which we come to believe in disembodied minds (Bloom 2004).

Cognitive science of religion indicates that religious belief, behavior, and experience are quite natural for the type of animal we are. Science, curiously enough, appears to be quite unnatural (McCauley 2011). Employing the language of maturation, McCauley, for instance, notes that there are two types of cognitive activity. One type comes to us quite naturally and matures naturally; the other takes some time and effort to master- that is to say, the other takes some practice. The reason for this is that the practiced type of cognition runs against the grain of the maturationally natural one. So-called practiced naturalness often results in thoroughly counterintuitive arguments and ultimately realizations. Science represents the pinnacle, so far, of practiced naturalness. 
Maturationally natural cognition reflects the evolutionary history of the human animal. The psychological proclivities associated with such cognition appear to be solutions to specific adaptive problems in what some call the environment of evolutionary adaptedness, or EEA (Tooby and Cosmides 1992). This environment is not merely a description of the flora and fauna of a particular geographical region; rather, it comprises the statistically significant recurrence of specific problems any one species faced and faces in its attempts to mature to reproductive fitness, to engage in successful reproduction, and to nurture progeny to reproductive maturity and success.

Specific to the human animal's struggle to survive and reproduce was and continues to be its particularly weak and slow physicality: our ancestors would have been and most likely were easily overtaken by faster and stronger animals - for instance, big cats and packs of dogs (Barrett 2005). The primary means for fending off such reproductive threats was sociality. Our ancestors had to band together and share information in order to survive. For this reason, they came to inhabit what Boyer calls "the cognitive niche" $(2001,120)$. Success in this particular niche required that our ancestors form the ability to infer that certain objects behave according to internally generated motivations - that is, some objects turn out to be agents. In order to infer the presence of agents, our ancestors developed a particular psychological capacity known today as a "theory of mind." Our theory of mind (ToM) enables us to take up the "intentional stance" as opposed to the "design stance" (Dennett 1989). Because of the intentional stance, we are able to interpret the behavior of certain objects as the result of internally generated desires, hopes, and intentions. This was crucial to our ancestors' survival. Insofar as other sentient objects, or agents, were vital not only to our survival but also our potential demise, our species eventually developed a trip-wired capacity to attribute agency where there in fact may be none. This trip-wired function has been called the "hyperactive agency detection device," or HADD (Barrett 2004).

Though a survival advantage for our ancestors—and maybe still for us today - the HADD leads us to commit many Type I errors. Type I errors pertain to sensing patterns where patterns do not exist, an error resting on the same spectrum with apophenia and schizophrenia. It is not, of course, hard to recognize the survival advantage of this cognitive error. A redeployed Pascalian wager proves the point: it always makes good survival sense to bet, under conditions of perceptual ambiguity to be sure, that something is an agent or the result of agent causation rather than the other way around. For instance, if you are not sure that the dark "blob" off the hiking trail ahead is a boulder or a bear, you should probably bet it is a bear first (Guthrie 1993). This is precisely what we do: we bet on agency far more often than not. Insofar as this is the case, we tend to 
socialize nonsocial realities. Who hasn't at some point cursed a computer that crashes or pleaded with a car that will not start? Socially cajoling insentient objects is a mistake. Accordingly, we either enjoy or suffer from a hypertrophied social intelligence (Boyer 2001, 122).

Our promiscuous social psychology constitutes what McCauley calls maturationally natural cognition. We sense agents everywhere, and we default to agent causation more often than not when engaged in explanatory tasks. We are indeed most fond of asking questions of this sort: “Who made/did X?" as opposed to "What made/did X?" Narrative explanations dealing with agents and intentions appear far more satisfying, especially when we broach some of the more meaningful existential questions pertaining to cosmogony and anthropology (Keleman 2004). Despite the fact that we have had no experience of the disembodied minds to which religions continually attest, our psychological proclivities appear to get the best of us most of the time. McCauley rightly notes, "Narrative activation of theory of mind systems can imbue an utterly improbable chain of events with a plausibility and fascination that human minds not only find engaging but convincing" $(2011,186)$. Here's the catch. We know that our social psychological intuitions get it wrong. How, then, in the absence of any empirical evidence, can we be sure that religion is not at the end of the day one grand Type I error-that is, cognitive illusion? We cannot. This leads me to believe that it in fact is a cognitive illusion. I further believe this is the case with the dharma traditions of South Asia. Yogic perception results from the promiscuity of our social psychology in general and our theory of mind in particular. Herein rests the cognitive distinction between religion and science.

The religion and science affair is ultimately a discussion concerning the rationally warranted range and scope of attributions involving agents and agent causation. Indeed, "scientific abstemiousness regarding intentional agents and their putative actions is to be compared with... religions' pervasive recruitment of theory of mind and appeals to agent explanations"(McCauley 2011, 232). Religious traditions and the theologies that eventually develop therefrom presume the preeminence of mind over matter and as such are committed to, at the very least, substance dualism, and quite often with the Hindu traditions, idealistic monism. Either way, consciousness is irreducible to material reality (Brown 2012). Fortunately or unfortunately, the overwhelming consensus in the mind sciences today indicates that both substance dualism and idealistic monism are incorrect. When Edelmann suggests that the Bhaggavata tradition need not worry about the mind-body dilemma so endemic to Western philosophical debates, he does so on the premise that the Hindu traditions understand that mind and body are part of a larger genre of material reality (prakrti) and that consciousness (purusa) is separate from such reality. This position, however, is based solely on first person testimony, which once 
again amounts to nothing more than anecdote. What is more, accepting first-person testimony would seem to overlook a truism in the sciences today:

Believers, like human beings generally, have no automatic, privileged, incorrigible entrée to the true nature of their behavior. The fact that they are the subject of their behavior is almost coincidental. It scarcely entails that they are the best, let alone sole, judge of it. Their own view may in fact prove the correct one, but not simply because it is their view. (Segal 1983,114)

The theology that follows fares no better. To be sure, "modern science's challenge to spiritual beliefs cannot be avoided by philosophical maneuvers" (Edis 2008, 125). Theology's disputatious obfuscations amount to nothing more than such philosophical maneuvers. There is simply no supporting evidence for the theological positions of the Bhägavata Purāna.

I do not believe there is anything the Bhaggavata Purana has to offer contemporary biological theory. Insofar as the Hindu traditions indulge our hypertrophied social intelligence, they seem presently unfit for dialogue with any of the natural sciences. The indisputable, cumulative, practical success of the natural sciences suggests that the inference to the best explanation for such success is that physicalism is in fact true. Despite metaphysical intuitions to the contrary, consciousness appears to be a property of a very complex, physical system. When that physical system deteriorates-as all physical systems eventually do-then consciousness deteriorates with it. It would seem the time is nigh to recognize that our intentional stance is simply mistaken when it comes to explaining and understanding the physical, chemical, and biological worlds. The design stance at the heart of the scientific enterprise holds out the best hope for our understanding of what is true and for realizing what is illusory. In this regard, a mature Indology must follow Wiebe's counsel concerning a mature science of religion:

A science of religion ... is not an autonomous enterprise that is ultimately free from the constraints of the other sciences but must rather recognize them as constituting "boundary conditions" that affect the range of theories of religion reasonably open to the Religious Studies enterprise. That is, those theories will have to locate themselves within what might be called an "integrated causal model" of the sciences and, consequently, will be "reductionistic" in that they will attempt to explain "the supernatural" naturalistically. All explanatory work and theoretical accounts of religion within the Religious Studies framework, therefore, will have to fall within the same conceptual and causal framework used to explain all other elements and aspects of the natural and social worlds. (2006, 691-92)

The same indeed holds for Indology: any theory pertaining to data issuing from the South Asian subcontinent must be constrained by the conceptual and causal frameworks of the natural and social sciences. Although many Indologists may be hesitant to accept this, it is the future of Indology. Appeals to take seriously indigenous philosophy and theology are 
simply unconvincing. Until there is some extraordinary evidence for what remains interminably anecdotal "evidence," I see no consilience between Hinduism's yogic perceptions and science as we now know it. Accordingly, and to paraphrase Mark C. Taylor, it would appear that Bhägavata theology is as dead as the Vishnu for which it searches.

\section{REFERENCES}

Avalos, Hector. 2005. Fighting Words: The Origins of Religious Violence. Amherst: Prometheus Books.

Baggini, Julian. 2003. Atheism: A Very Short Introduction. Oxford: Oxford University Press.

Barrett, H. Clark. 2005. "Adaptations to Predators and Prey." In The Handbook of Evolutionary Psychology, ed. D. M. Buss, 200-23. Hoboken, NJ: John Wiley \& Sons, Inc.

Barrett, Justin. L. 2004. Why Would Anyone Believe in God? Lanham, MD: AltaMira Press.

Bloom, Paul. 2004. Descartes' Baby: How the Science of Child Development Explains What Makes Us Human. New York: Basic Books.

Boyer, Pascal. 2001. Religion Explained: The Evolutionary Origins of Religious Thought. New York: Basic Books.

2010. The Fracture of an Illusion: Science and the Dissolution of Religion. Gottingen: Vandenhoeck \& Ruprecht GmbH \& Co.

Brown, C. Mackenzie. 2012. Hindu Perspectives on Evolution: Darwin, Dharma, and Design. New York: Routledge.

Carroll, Sean. B. 2006. Endless Forms Most Beautiful: The New Science of Evo Devo. New York: W. W. Norton \& Co.

Churchland, Paul. M. 1988. Matter and Consciousness, Rev. ed. Cambridge: Massachusetts Institute of Technology.

Dawkins, Richard. 2006. The God Delusion. Boston: Houghton Mifflin Co.

Dennett, Daniel. C. 1989. The Intentional Stance. Cambridge: MA: Massachusetts Institute of Technology.

1991. Consciousness Explained. Boston: Little, Brown and Co.

1995. Darwin's Dangerous Idea: Evolution and the Meanings of Life. New York: Simon \& Schuster.

- 2006. Breaking the Spell: Religion as a Natural Phenomenon. New York: Viking.

Edelmann, Jonathan B. 2012. Hindu Theology and Biology: The Bhägavata Puraña and Contemporary Theory. Oxford: Oxford University Press.

Edis, Taner. 2008. Science and Nonbelief. Amherst, NY: Prometheus Books.

Ellis, Thomas B. 2008. "Of And and $O f$ : The Politics of Grammar and the Study of Religion." Method \& Theory in the Study of Religion 20:270-90. 2009. "I Love You, I Hate You: Toward a Psychology of the Hindu Deus Absconditus." International Journal of Hindu Studies 13:1-23.

2011. "Disgusting Bodies, Disgusting Religion: The Biology of Tantra." Journal of the American Academy of Religion 79:879-927.

Fitzgerald, Timothy. 2000. The Ideology of Religious Studies. New York: Oxford University Press. Flanagan, Owen. 2002. The Problem of the Soul: Two Visions of Mind and How to Reconcile Them. New York: Basic Books. 2007. The Really Hard Problem: Meaning in a Material World. Cambridge, MA: The MIT Press. 2011. The Bodhisattva's Brain: Buddhism Naturalized. Cambridge, MA: Massachusetts Institute of Technology.

Flood, Gavin D. 1996. An Introduction to Hinduism. New York: Cambridge University Press.

Forrest, Barbara. 2000. "Methodological Naturalism and Philosophical Naturalism: Clarifying the Connection." Philo 3:7-29.

Franco, Eli. 1987. Perception, Knowledge and Disbelief: A Study of Jayarasi's Scepticism. Stuttgart: Franz Steiner Verlag Wiesbaden GmbH.

Freud, Sigmund. 1927. The Future of an Illusion. London: Hogarth Press. 
Gross, Paul. R. and Norman Levitt. 1994. Higher Superstition: The Academic Left and Its Quarrels with Science. Baltimore, MD: The Johns Hopkins University Press. Guthrie, Stewart Elliott. 1993. Faces in the Clouds: A New Theory of Religion. New York: Oxford University Press.

Harris, Sam. 2007. "Science Must Destroy Religion.” In What Is Your Dangerous Idea?: Today's Leading Thinkers on the Unthinkable, ed. J. Brockman. London: Harper Perennial.

2012. Free Will. New York: Free Press.

Haught, John F. 2008. God and the New Atheism: A Critical Response to Dawkins, Harris and Hitchens. Louisville, KY: Westminster John Knox Press.

Inden, Ronald. B. 1990. Imagining India. Oxford, UK, and Cambridge, MA: Basil Blackwell. Kelemen, Deborah. 2004. "Are Children "Intuitive Theists"?

Reasoning about Purpose and

Design in Nature." Psychological Science 15:295-301.

Kim, Jaegwon. 2005. Physicalism, Or Something Near Enough. Princeton: Princeton University Press.

Koch, Christof. 2004. The Quest for Consciousness: A Neurobiological Approach. Englewood: Roberts \& Company Publishers.

Koertge, Noretta., Ed. 1998. A House Built on Sand: Exposing Postmodernist Myths About Science. New York: Oxford University Press.

Krauss, Lawrence. M. 2012. A Universe from Nothing: Why There Something Rather Than Nothing. New York: Free Press.

Kuhn, Thomas. S. 1962. The Structure of Scientific Revolutions. Chicago: The University of Chicago Press.

Mackie, John. L. 1982. The Miracle of Theism: Arguments for and against the Existence of God. Oxford: Oxford University Press.

Masson, J. Moussaieff. 1976. "The Psychology of the Ascetic." Journal of Asian Studies 35:611-25. 1980. The Oceanic Feeling: The Origins of Religious Sentiment in Ancient India. Dordrecht, Holland, and Boston: D. Reidel Pub. Co.

McCauley, Robert N. 2011. Why Religion Is Natural and Science Is Not. Oxford: Oxford University Press.

McCutcheon, Russell T. 2001. Critics Not Caretakers: Redescribing the Public Study of Religion. Albany: State University of New York Press.

Newberg, Andrew B., Eugene G. D'Aquili, et al. 2001. Why God Won't Go Away: Brain Science and the Biology of Belief. New York: Ballantine Books.

Persinger, Michael A. 1987. Neuropsychological Bases of God Beliefs. New York: Praeger Publishers. Pyszczynski, Thomas A., Sheldon Solomon, and Jeff Greenberg. 2003. In the Wake of 9/11: The Psychology of Terror. Washington, DC: American Psychological Association.

Revonsuo, Antti. 2000. "The Reinterpretation of Dreams: An Evolutionary Hypothesis of the Function of Dreaming." Brain Sciences 23:877-901.

Searle, John R. 2005. Mind: A Brief Introduction. New York: Oxford University Press.

Segal, Robert. A. 1983. "In Defense of Reduction." Journal of the American Academy of Religion 51:97-124.

Shermer, Michael. 2011. The Believing Brain: From Ghosts and Gods to Politics and Conspiracies- How We Construct Beliefs and Reinforce Them as Truths. New York: Times Books.

Stenger, Victor J. 2009. The New Atheism: Taking a Stand for Science and Reason. Amherst: Prometheus Books.

Taves, Ann. 2009. Religious Experience Reconsidered: A Building-Block Approach to the Study of Religion and Other Special Things. Princeton: Princeton University Press.

Thagaard, Paul. 2010. The Brain and the Meaning of Life. Princeton: Princeton University Press. Tooby, John, and Leda Cosmides 1992. "The Psychological York: Oxford University Press.

Wiebe, Donald. 2000. The Politics of Religious Studies: The Continuing Conflict with Theology in the Academy. New York: Palgrave.

. 2006. "An Eternal Return All Over Again: The Religious Conversation Endures." Journal of the American Academy of Religion 74:674-96.

Wilson, Edward. O. 1998. Consilience: The Unity of Knowledge. New York: Knopf.

Young, Matt, and Taner Edis, eds. 2004. Why Intelligent Design Fails: A Scientific Critique of the New Creationism. New Brunswick: Rutgers University Press 